\author{
ANNA JAŃSKA* \\ InterRisk Towarzystwo Ubezpieczeń \\ Spółka Akcyjna Vienna Insurance Group
}

\title{
OCENA RYZYKA W PROCESIE UDZIELANIA UBEZPIECZENIOWYCH GWARANCJI KONTRAKTOWYCH
}

Słowa kluczowe: gwarancja, gwarancja kontraktowa, zarządzanie ryzykiem. Klasyfikacja JEL: D81, G32.

\begin{abstract}
Abstrakt: W artykule omówiono problematykę oceny ryzyka w procesie udzielania gwarancji ubezpieczeniowych na przykładzie gwarancji kontraktowych, zabezpieczających wszystkie etapy procesu inwestycyjnego: od gwarancji zapłaty wadium, przez gwarancje należytego wykonania kontraktu, zwrotu zaliczki, aż po gwarancję właściwego usunięcia wad i usterek. Szczególną uwagę zwrócono na wyjątkowy charakter gwarancji ubezpieczeniowych, które różnią się istotnie od pozostałych ubezpieczeń działu II. Specyficzne cechy gwarancji mają decydujący wpływ na kształt procesu oceny ryzyka. W artykule scharakteryzowano czynniki wpływające na poziom ryzyka związanego z działalnością gwarancyjną, przeanalizowano wymagania, jakim muszą sprostać klienci ubiegający się o gwarancje, oraz omówiono poszczególne etapy procesu oceny ryzyka.
\end{abstract}

\section{RISK APPRAISAL IN THE AWARD OF CONTRACT BONDS}

Keywords: contract bond, guarantee, risk management.

JEL Classification: D81, G32.

Abstract: The article discusses the problem of risk appraisal illustrated with an example of the contract bonds at all steps of the investment process: bid bonds, performance bonds, advance payment bonds and maintenance bonds. Particular attention was paid to the nature of the insurance guarantees, which differs significantly from other

Data wpłynięcia: 25.03.2013; data zaakceptowania: 24.04.2013.

* Dane kontaktowe: Anna.Janska@interrisk.pl. 
non-life insurance. Furthermore, the risk assessment process is determined by specific characteristics of the guarantees. This paper includes the description of factors affecting the level of risk associated with the guarantee. It discusses the different stages of risk estimation and insurers' requirements for the customers applying for guarantees.

Translated by Anna Jańska

\section{WSTĘP}

Ocena ryzyka w procesie udzielania gwarancji ubezpieczeniowych stanowi kluczowy czynnik decydujący o przyjęciu danego podmiotu do ochrony. Głównym celem analizy jest więc odpowiedź na pytanie, czy dana gwarancja może być danej firmie udzielona. Gwarancji powinno udzielać się zgodnie z zasadą „zerowego ryzyka”, czyli wtedy i tylko wtedy, gdy po przeprowadzonej ocenie ryzyka analityk jest przekonany, że nie nastąpi wypłata na żądanie beneficjenta. Od sposobu, w jaki zostanie przeprowadzona ocena, zależy w dużej mierze wynik finansowy działalności gwarancyjnej ubezpieczyciela. W artykule omówiono problematykę oceny ryzyka w procesie udzielania gwarancji ubezpieczeniowych na przykładzie gwarancji kontraktowych, zabezpieczających wszystkie etapy procesu inwestycyjnego: od gwarancji zapłaty wadium, przez gwarancje należy tego wykonania kontraktu, zwrotu zaliczki, aż po gwarancję właściwego usunięcia wad i usterek. Zdefiniowano i sklasyfikowano gwarancje ubezpieczeniowe, a szczególną uwagę zwrócono na wyjątkowy charakter gwarancji ubezpieczeniowych, które różnią się istotnie od pozostałych ubezpieczeń działu II. Specyficzne cechy gwarancji mają decydujący wpływ na kształt procesu oceny ryzyka. $\mathrm{W}$ artykule scharakteryzowano czynniki wpływające na poziom ryzyka związanego z działalnością gwarancyjną, przeanalizowano wymagania, jakim muszą sprostać klienci ubiegający się o gwarancje, oraz omówiono poszczególne etapy procesu oceny ryzyka: z perspektywy ryzyka zobowiązanego oraz ryzyka danego kontraktu.

\section{POJĘCIE I ISTOTA GWARANCJI UBEZPIECZENIOWYCH}

Podejmując próbę zdefiniowania pojęcia "gwarancja ubezpieczeniowa”, napotykamy problemy wynikające $\mathrm{z}$ samej istoty procesu gwarantowania. Trudności definicyjne powoduje również fakt, że brakuje zarówno definicji ustawowej, jak i jednomyślności wśród teoretyków ubezpieczeń. 
W świetle Ustawy z dnia 22 maja 2003 roku o działalności ubezpieczeniowej (art. 3 ust. 3 pkt 1 ustawy) gwarancja jest jedną z czynności ubezpieczeniowych, nie jest jednak umową ubezpieczenia z punktu widzenia konstrukcji prawnej. W literaturze przedmiotu gwarancję ubezpieczeniową definiuje się jako świadczenie woli zakładu ubezpieczeń (gwaranta), który zobowiązuje się do udzielenia określonego świadczenia pieniężnego gwarantariuszowi (wierzycielowi, beneficjentowi gwarancji) w przypadku, gdy dłużnik (zobowiązany, zleceniodawca gwarancji) nie wywiąże się z przyjętego zobowiązania wobec beneficjenta gwarancji (Holly 2004: 79). Równie często spotykana definicja charakteryzuje gwarancję ubezpieczeniową jako jednostronne zobowiązanie zakładu ubezpieczeń (gwaranta) do wypłacenia świadczenia pieniężnego na rzecz podmiotu uprawnionego (beneficjenta) w sytuacji, gdy podmiot wnioskujący o wydanie gwarancji nie wywiązał się z ustalonego wobec beneficjenta obowiązku (Michalik, Seliga 2001: 291). Specyficzny, wyrastający z praktyki, charakter tego rodzaju produktów ubezpieczeniowych potwierdził niejako Sąd Apelacyjny w Poznaniu w orzeczeniu z dnia 11 stycznia 2006 roku (I ACa 761/05), orzekając, że „gwarancje ubezpieczeniowa jest specyficzną, niestypizowaną, a ukształtowaną głównie przez praktykę, czynnością ubezpieczeniową, znajdującą oparcie prawne przede wszystkim w zasadzie swobody układania stosunków zobowiązaniowych" (Kodeks cywilny, art. 353[1]).

Gwarancja jest umową nienazwaną, więc tyko jej treść decyduje o prawach i obowiązkach stron. Nie przypomina klasycznie rozumianego ubezpieczenia, a charakterem zbliża się bardziej do papierów wartościowych, takich jak np. weksel. Do pozostałych specyficznych cech gwarancji ubezpieczeniowych należy zaliczyć fakt, że wypłata z tytułu gwarancji zawsze skutkuje regresem i że do gwarancji nie mają zastosowania przepisy ubezpieczeniowe, a raczej normy kodeksowe oraz, pomocniczo, zawarte w art. 80-83 i 87 prawa bankowego (Sikora 2012). Co do samej konstrukcji prawnej, gwarancja bankowa nie różni się niczym (poza nazwą wynikającą z osoby gwaranta) od gwarancji ubezpieczeniowej (Kukiełka, Poniewierka 2003: 76).

Relacja gwarantowania ma charakter trójstronny i stanowi relację między gwarantem (ubezpieczycielem), zobowiązanym (wykonawcą) oraz beneficjentem gwarancji (inwestorem). Między każdym z podmiotów następuje przepływ dokumentów oraz informacji, co zostało w pełni zobrazowane na schemacie 1. 
Schemat 1. Trójstronny charakter relacji gwarantowania

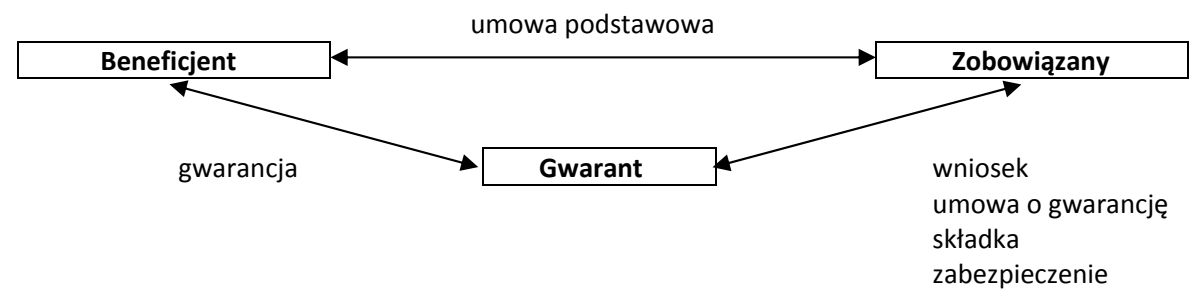

Źr ó dło: opracowanie własne.

Gwarancje ubezpieczeniowe odgrywają na rynku istotną rolę i przynoszą stronom umowy liczne korzyści. Jedną z podstawowych zalet stosowania gwarancji w obrocie gospodarczym jest poprawa płynności przedsiębiorstwa. Staje się tak za sprawą dwojakich przyczyn:

- firma uzyskująca gwarancję unika angażowania własnych środków finansowych w celu złożenia zabezpieczeń wymaganych przez kontrahentów,

- jeśli wcześniejsze zabezpieczenia ustanowiono w gotówce (np. w formie jednorazowo wpłaconej kaucji lub systematycznych potrąceń z faktur), przedstawienie gwarancji stwarza możliwość odblokowania zabezpieczeń finansowych złożonych do wcześniej zawartych kontraktów.

Zwiększenie płynności przekłada się z kolei na poprawę konkurencyjności podmiotu zlecającego udzielenie gwarancji dzięki możliwości m.in. uczestniczenia w wielu przetargach jednocześnie bądź ulokowania środków finansowych w inny, alternatywny sposób (np. przeznaczenie ich na inwestycje). Ponadto, wybierając gwarancję ubezpieczeniową, firma nie zmniejsza swojej zdolności kredytowej w banku jak w przypadku wykorzystaniu gwarancji bankowych (wszystkie produkty bankowe są sumowane w ramach przyznanych limitów). Fakt uzyskania gwarancji przyczynia się również do pewnego rodzaju „efektu wizerunkowego” - dowodzi bowiem, że firma została przebadana i pozytywnie zaopiniowana przez analityków ubezpieczyciela, co jest swoistym potwierdzeniem wiarygodności wobec kontrahentów.

\section{KLASYFIKACJE I RODZAJE GWARANCJI}

Gwarancje ubezpieczeniowe ustawowo sklasyfikowano jako grupę 15. Działu II ubezpieczeń (tj. „Pozostałe ubezpieczenia osobowe oraz ubezpieczenia 
majątkowe") z wyszczególnieniem gwarancji bezpośrednich oraz pośrednich, czyli regwarancji. W powszechnym nazewnictwie stosuje się często zamiennie pojęcie gwarancji ubezpieczeniowych oraz ubezpieczeń finansowych, co z punktu widzenia terminologii jest błędnym uproszczeniem, gdyż gwarancje stanowią jedynie jeden z rodzajów ubezpieczeń finansowych, obok różnego rodzaju ubezpieczeń kredytów.

W literaturze przedmiotu możemy spotkać wiele klasyfikacji gwarancji. Z uwagi na charakter zobowiązania wyróżnia się gwarancje warunkowe oraz bezwarunkowe (Holly 2004: 88). Różnica między nimi urzeczywistnia się w momencie zgłoszenia żądania zapłaty przez beneficjenta gwarancji - w przypadku gwarancji warunkowej ubezpieczyciel przed dokonaniem wypłaty bada, czy wymogi (warunki) wyszczególnione w treści gwarancji zostały spełnione.

Międzynarodowe Stowarzyszenie Ubezpieczenia Kredytu (International Credit Insurance and Surety Association) wyróżnia główne typy gwarancji ubezpieczeniowych (Holly 2004: 91):

- gwarancje kontraktowe,

- gwarancje zapłaty należności celno-podatkowych,

- gwarancje od sprzeniewierzenia,

- gwarancje koncesyjne,

- gwarancje zapłaty czynszu,

- gwarancje wykonania dostawy.

Na polskim rynku najpopularniejszy jest pierwszy rodzaj gwarancji, tj. gwarancje kontraktowe, obejmujące swoim zakresem gwarancje zapłaty wadium, należytego wykonania kontraktu, zwrotu zaliczki oraz właściwego usunięcia wad i usterek. Zastosowanie gwarancji kontraktowych umożliwia zabezpieczenie pełnego procesu inwestycyjnego, co zobrazowano w tabeli 1 . Warto również zwrócić uwagę, że w praktyce na polskim rynku ryzyko prawidłowego wykonania dostawy nie jest zabezpieczane oddzielnym rodzajem gwarancji, ale stosuje się $w$ tych przypadkach schematy typowe dla gwarancji należytego wykonania umowy - jako że warunki dokonania dostawy są określone w ramach umowy, którą dana gwarancja ma zabezpieczać.

Gwarancje koncesyjne stanowi przede wszystkim gwarancja dla organizatora turystyki i pośrednika turystycznego, której ramy są doprecyzowane ustawowo, zgodnie z Rozporządzeniem Ministra Sportu i Turystyki z dnia 21 kwietnia 2011 roku (Dz.U. z 2011 r., nr 88, poz. 499). Rozporządzenie wprowadza wzory formularzy umowy gwarancji bankowej, umowy gwarancji ubezpieczeniowej oraz umowy ubezpieczenia na rzecz klientów, które są wymagane 
w polskim prawie od firm prowadzących przedsięwzięcia określane mianem „działalności wykonywanej przez organizatorów turystyki i pośredników turystycznych". Wśród gwarancji celno-podatkowych należy wymienić najpopularniejsze z nich, m.in. gwarancja zapłaty długu celnego, gwarancja procedury tranzytowej (WPT) oraz gwarancje dla przewoźników korzystających z systemu TIR. Z kolei gwarancje zapłaty czynszu, bardzo często pożądane przez klientów, są aktualnie marginalizowane przez ubezpieczycieli z uwagi na bardzo wysokie ryzyko i rosnącą szkodowość, jaka urzeczywistnia się za każdym razem $w$ fazie kryzysu gospodarczego.

Tabela 1. Rodzaje gwarancji stosowane w poszczególnych etapach procesu inwestycyjnego

\begin{tabular}{|c|c|c|c|}
\hline Lp. & Etap realizacji inwestycji & Rodzaj stosowanej gwarancji & \multirow{5}{*}{ 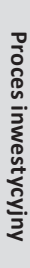 } \\
\hline I & przetarg & gwarancja zapłaty wadium & \\
\hline II & podpisanie umowy & gwarancja należytego wykonania kontraktu & \\
\hline III & wypłata zaliczki & gwarancja zwrotu zaliczki & \\
\hline IV & zakończenie robót & gwarancja właściwego usunięcia wad i usterek & \\
\hline
\end{tabular}

Źr ó d ło: opracowanie własne.

\section{GWARANCJE UBEZPIECZENIOWE NA POLSKIM RYNKU}

Rozwój gwarancji ubezpieczeniowych na polskim rynku, zobrazowany wartością i dynamiką składki przypisanej brutto, w odniesieniu do zmian PKB w latach przedstawiono w tabeli 2. Lata 2000-2003 były dla ubezpieczeń grupy 15. okresem stagnacji. Mimo rosnącego PKB, na rynku gwarancji następował systematyczny, choć nie gwałtowny spadek przypisu składki. Dopiero rok 2003 okazał się przełomowy - od tego czasu przypis wzrastał dynamicznie w każdym roku, zwiększając ponadto udział składki z gwarancji w PKB. Osłabienie wyników nastąpiło po siedmiu latach - w roku 2011. W wyniku kryzysu i na skutek licznych upadłości firm (głównie budowlanych, jak również turystycznych) ubezpieczyciele zaczęli ograniczać ryzyko i limitować wystawianie gwarancji, co znalazło odzwierciedlenie w niższym poziomie przypisu składki brutto i mniejszym udziale składki z gwarancji w PKB. 
III OCENA RYZYKA W PROCESIE UDZIELANIA UBEZPIECZENIOWYCH GWARANCJI...

Tabela 2. Wartość i dynamika składki przypisanej brutto z tytułu gwarancji ubezpieczeniowych w odniesieniu do PKB w latach 2000-2011

\begin{tabular}{|c|c|c|c|c|}
\hline \hline Lata & $\begin{array}{c}\text { Wartość składki przypisanej } \\
\text { brutto z tytułu gwarancji ubez- } \\
\text { pieczeniowych (w mln zł) }\end{array}$ & $\begin{array}{c}\text { Dynamika } \\
\text { rok do roku } \\
\text { (w proc.) }\end{array}$ & $\begin{array}{c}\text { PKB Polski } \\
\text { (w mln zł) }\end{array}$ & $\begin{array}{c}\text { Udział składki } \\
\text { z gwarancji w PKB } \\
\text { (w promilach) }\end{array}$ \\
\hline \hline 2000 & 148,782 & 109,43 & 744378 & 0,200 \\
\hline 2001 & 136,476 & 91,73 & 779564 & 0,175 \\
\hline 2002 & 114,537 & 83,92 & 808578 & 0,142 \\
\hline 2003 & 112,704 & 98,40 & 843156 & 0,134 \\
\hline 2004 & 120,603 & 107,01 & 924538 & 0,130 \\
\hline 2005 & 136,116 & 112,87 & 983392 & 0,138 \\
\hline 2006 & 150,245 & 110,38 & 1060031 & 0,149 \\
\hline 2007 & 187,017 & 137,40 & 1176737 & 0,169 \\
\hline 2008 & 214,973 & 114,95 & 1275432 & 0,206 \\
\hline 2009 & 277,301 & 129,40 & 1343657 & 0,225 \\
\hline 2010 & 317,968 & 114,67 & 1415385 & 0,199 \\
\hline 2011 & 302,842 & 95,24 & 1524679 & 0 \\
\hline \hline
\end{tabular}

Źr ó dło: opracowanie własne na podstawie: Nowak 2011 oraz dane ze strony www.knf.gov.pl i www.stat.gov.pl.

Na lata 2012-2013 ubezpieczyciele również nie przewidują poprawy wyników z działalności gwarancyjnej. Według wstępnych danych, w 2012 roku firmy ubezpieczeniowe w Polsce poniosły na tej linii biznesowej straty (co w ostatnich latach w ogóle się nie zdarzało), wypłacając z tytułu gwarancji kwotę pięciokrotnie wyższą niż w 2011 roku, tj. 422,9 mln zł, z czego 63 mln zł w pierwszym, a blisko 360 mln zł w drugim półroczu (Glapiak 2013). Mimo że scenariusz pesymistyczny przewidywał stratę ponad dwukrotnie większą - szacowano bowiem, że kryzys może kosztować towarzystwa nawet 1 mld zł (Gawrychowski 2012), to i tak w efekcie większość ubezpieczycieli znacząco ograniczyła udzielanie gwarancji, lub nawet zrezygnowała z tego zupełnie. Spektakularne bankructwa oraz problemy finansowe firm budowlanych czy turystycznych spowodowały, że ubezpieczyciele kontynuują zaostrzoną politykę sprzedaży gwarancji i dokładniejsze badanie sytuacji finansowej firm również w roku 2013 (Glapiak 2013), co znajdzie odzwierciedlenie w poziomie składki przypisanej brutto i udziale gwarancji w PKB. 


\section{RYZYKO GWARANTA}

Gwarancje są dla firm ubezpieczeniowych specyficznym produktem m.in. ze względu na źródła ryzyka. W przypadku gwarancji ubezpieczeniowych mamy do czynienia z jednostkową oceną ryzyka (Wierzbicka 2007: 115), gdyż nie jest możliwe statystyczne oszacowanie prawdopodobieństwa wystąpienia szkody. Do elementów wpływających na poziom ryzyka związanego z działalnością gwarancyjną zalicza się (Kukiełka, Poniewierka 2003: 87-90):

- znaczną fluktuację poziomów szkodowości: gwarancje ubezpieczeniowe charakteryzują się bardzo wysoką zależnością wyników technicznych od zmian koniunktury gospodarczej. W czasie wzrostu gospodarczego generują wysoki poziom przypisu składki przy niezwykle niskim poziomie szkodowości, w fazie kryzysu zaś można odnotować nawet kilkusetprocentowe wskaźniki szkodowości. Na polskim rynku w 2012 roku oszacowano, że kryzys w samej branży budowlanej mógł kosztować firmy ubezpieczeniowe nawet 1 mld zł. Ubezpieczyciele zabezpieczają bowiem kontrakty warte łącznie od 25 do 30 mld zł, co przekracza wartość całego rynku majątkowego. Teoretyczne uruchomienie 10\% udzielonych gwarancji mogłoby poważnie wpłynąć na wyniki finansowe towarzystw ubezpieczeniowych (www.money.pl);

- brak (lub bardzo niewielki poziom) wpływu na zmiany poziomu ryzyka w okresie gwarantowania: nawet jeśli ubezpieczyciel jest informowany o negatywnych zjawiskach u zobowiązanego, ma niewielkie możliwości reakcji na zmiany w kształcie ryzyka i nie może w żaden sposób zmniejszyć swojej odpowiedzialności z tytuły udzielonych gwarancji;

- długi okres gwarantowania: im dłuższy okres gwarancji, tym bardziej niepewna staje się prognoza dotycząca przyszłej sytuacji zobowiązanego. W przypadku wieloletnich terminów odpowiedzialności mogą zajść również istotne zmiany o charakterze makroekonomicznym (ryzyko polityczne itp.);

- duża rygorystyczność zobowiązania gwaranta: większość funkcjonujących na rynku gwarancji ma charakter nieodwołalny i bezwarunkowy, w związku z czym w przypadku zaistnienia szkody możliwości wpływu gwaranta na zaistniałą sytuację są niewielkie. Ubezpieczyciel nie ma bowiem wpływu na fakt niewykonania zobowiązania przez zleceniodawcę gwarancji; 
- jednostkowe występowanie szkód i dominacja szkód w maksymalnej wysokości: relacja ilości szkód do ilości udzielonych gwarancji jest relatywnie niewielka w porównaniu do innych ubezpieczeń majątkowych. Jednak te jednostkowe szkody są zwykle wezwaniami do maksymalnej sumy gwarancyjnej lub bardzo jej bliskiej, przy czym najwięcej wypłat odnotowuje się pod koniec okresu gwarantowania;

- aspekty dodatkowe - inne niż wynik oceny ryzyka: często między stronami umowy o udzielenie gwarancji dochodzi do pewnego rodzaju szantażu. Stali klienci, lokujący w danym towarzystwie cały portfel ubezpieczeń, grożą zakończeniem współpracy, jeśli nie uzyskają danej gwarancji. Z kolei ubezpieczyciele, dążąc do zwiększania przypisu składki, mogą uzależniać wydanie gwarancji na daną inwestycję od zawarcia dodatkowych ubezpieczeń z nią związanych (cross-selling np. w ramach gwarancji i ubezpieczeń ryzyk budowy czy też odpowiedzialności cywilnej). Tego rodzaju praktyki mogą znacznie pogorszyć wyniki działalności gwarancyjnej; decyzja o przyjęciu lub odrzuceniu ryzyka powinna być dokonywana w sposób obiektywny i niezależny;

- inne: hazard motywacyjny, ryzyko nadużycia: w przypadku kontraktów zabezpieczonych gwarancjami (a nie np. gotówką) może dochodzić do nieetycznych zachowań zarówno ze strony zobowiązanego, jak i beneficjenta gwarancji. Ze zjawiskiem hazardu motywacyjnego zetkniemy się w sytuacji, gdy beneficjent przestanie starannie dobierać kontrahentów, wychodząc z założenia, że ryzyko i tak jest zabezpieczone gwarancją. Nie będzie wtedy również szedł na ustępstwa i kompromisy w sytuacjach spornych, np. nie wydłuży terminu wykonania zadania. Zobowiązany z kolei może zacząć traktować gwarancję jaką formę nieoprocentowanego kredytu kupieckiego - w przypadku gwarancji handlowych. Jednak tego rodzaju praktyki mogą szybko uniemożliwić uzyskanie kolejnych zabezpieczeń. Ryzyko nadużycia występuje z kolei po stronie beneficjenta w sytuacjach sporu z zobowiązanym. W przypadku gwarancji bezwarunkowch beneficjenci grożą uruchomieniem gwarancji, jeśli zobowiązany nie spełni ich postulatów.

\section{OCENA RYZYKA ZWIĄZANEGO Z UDZIELENIEM GWARANCJI}

Proces oceny ryzyka związanego z udzieleniem gwarancji polega w głównej mierze na zbadaniu aktualnej zdolności klienta do regulowania zobowiązań 
oraz prognozowaniu tej zdolności w obranym okresie gwarantowania. Ocenie podlega również potencjał i przygotowanie zobowiązanego do zrealizowania zadania określonego w umowie podstawowej oraz wartość likwidacyjna przedsiębiorstwa z uwzględnieniem możliwości windykacyjnych. Badaniu podlegają ponadto przyjmowane zabezpieczenia roszczeń zwrotnych (Holly 2004: 95-97), przez co cały proces oceny ryzka może przypominać badanie zdolności kredytowej przedsiębiorstwa.

Gwarancji powinno udzielać się zgodnie z zasadą „zerowego ryzyka”, czyli wtedy i tylko wtedy, gdy po przeprowadzonej ocenie ryzyka analityk jest przekonany, że nie nastąpi wypłata na żądanie beneficjenta (Kukiełka, Poniewierka 2003: 183).

Źródłem informacji dla gwaranta są wniosek o udzielenie gwarancji oraz liczne, aktualne załączniki do wniosku:

1. Dokumenty związane z rozpoczęciem działalności:

- dokumenty rejestrowe: np. aktualny KRS lub CEIDG,

- decyzja o nadaniu numeru NIP, REGON,

- aktualny statut spółki lub aktualna umowa spółki;

2. Zaświadczenia i opinie:

- zaświadczenie o braku zaległości w ZUS,

- zaświadczenie o braku zaległości w US,

- opinie wszystkich banków, z jakimi zobowiązany współpracuje;

3. Dokumenty finansowe (w zależności od formy prowadzenia księgowości, jeśli był obowiązek sporządzenia):

- bilanse oraz rachunki zysków i strat, rachunek przepływów, sprawozdanie biegłego rewidenta, informacja dodatkowa do bilansu za ostatni rok obrachunkowy, zestawienie zmian w kapitale własnym,

- deklaracje podatkowe osób fizycznych prowadzących działalność gospodarczą,

- sprawozdanie o przychodach, kosztach i wyniku finansowym oraz o nakładach na środki trwałe,

- F-01 lub deklaracje na miesięczną zaliczkę na podatek dochodowy od osób fizycznych,

- oświadczenie majątkowe dla osób fizycznych, spółek cywilnych, spółek jawnych;

4. Dokumenty dotyczące przedmiotu gwarancji:

- specyfikacja istotnych warunków zamówienia - dla gwarancji zapłaty wadium, 
- umowa - dla gwarancji należytego wykonania kontraktu, właściwego usunięcia wad i usterek, zwrotu zaliczki,

- protokół odbioru stwierdzający bezusterkowy odbiór robót - dla gwarancji właściwego usunięcia wad lub usterek;

5. Posiadane referencje;

6. Inne dokumenty (np. dla gwarancji zabezpieczających kontrakty współfinansowane przez Unię Europejską będzie to dokumentacja projektowa, wnioski o finansowanie, harmonogramy itp.).

Ocena ryzyka na podstawie powyższej dokumentacji przebiega dwutorowo: z jednej strony badane jest ryzyko zobowiązanego, z drugiej zaś - treść umowy podstawowej. Jednocześnie sprawdza się, czy dany zobowiązany jest w stanie podołać danemu kontraktowi: zarówno w sensie zdolności finansowych, jak i potencjału technicznego, intelektualnego oraz dotychczasowego doświadczenia w realizacji tego rodzaju zadań. Schemat 2 przedstawia ocenę ryzyka dla ubezpieczeniowej gwarancji kontraktowej.

Schemat 2. Ocena ryzyka dla ubezpieczeniowej gwarancji kontraktowej

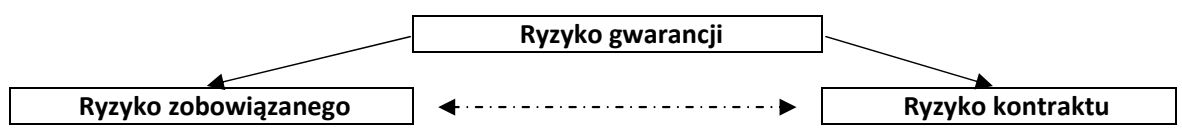

Źr ó dło : opracowanie własne.

Ocenę ryzyka zobowiązanego rozpoczyna weryfikacja formalna dokumentów oraz przegląd podstawowych danych w nich zawartych. Sprawdzeniu podlega m.in. fakt, jak długo przedsiębiorstwo działa na rynku, czy nie jest w stanie upadłości, czy przedsiębiorca nie zawiesił na dany moment działalności gospodarczej. Ocenia się ponadto, czy firma na bieżąco reguluje swoje zobowiązania wobec Zakładu Ubezpieczeń Społecznych oraz Urzędu Skarbowego i jak przebiega współpraca z bankami. Zaległości podatkowe, zaległości wobec ZUS czy też opóźnienia w spłacie kredytu są zwykle pierwszymi sygnałami, że firma ma problemy z płynnością i zachodzą w niej niekorzystne zjawiska. Pierwsza faza oceny ryzyka jest standaryzowana i w każdej firmie ubezpieczeniowej wygląda bardzo podobnie.

Kolejna faza oceny ryzyka zobowiązanego polega na przeprowadzeniu analizy finansowej, która jest głównym etapem oceny i obejmuje (Holly 2004: 97): analizę pionową i poziomą sprawozdań finansowych, analizę wskaźnikową 
oraz analizę porównawczą na podstawie przedłożonych przez zobowiązanego sprawozdań finansowych oraz informacji uzupełniających (oświadczeń, wyjaśnień dodatkowych itp.).

Analizie podlegają ponadto zabezpieczenia roszczeń regresowych klienta szacowana jest ich wartość aktualna i przyszła (w trakcie okresu gwarancyjnego), płynność, obciążenia na rzecz innych podmiotów. W przypadku stałych klientów, np. korzystających z gwarancji w ramach umów generalnych z limitem, niezbędne jest również sprawdzenie poziomu zaangażowania w czynne gwarancje oraz monitorowanie zabezpieczeń ustanowionych dla danego limitu.

Ryzyko kontraktu ocenia się na wstępie przez pryzmat polityki sprzedażowej gwaranta. Tak jak w przypadku innych ubezpieczeń majątkowych, ubezpieczyciele opracowują „czarne listy” tematów zakazanych i z założenia nie obejmują ich ochroną. Obostrzenia te mogą dotyczyć wybranych branż (np. budowa dróg), okresów odpowiedzialności (np. gwarancje kilkunasto- czy kilkudziesięcioletnie), sum gwarancyjnych (z uwagi na kwestie reasekuracyjne), rodzajów umów czy też treści gwarancji.

Kluczowym elementem oceny ryzyka kontraktu jest zbadanie treści dokumentu źródłowego, z którego wynika potrzeba wystawienia gwarancji. Są to:

- specyfikacja istotnych warunków zamówienia - dla gwarancji zapłaty wadium,

- umowa - dla gwarancji należytego wykonania kontraktu, właściwego usunięcia wad i usterek, zwrotu zaliczki,

- protokół stwierdzający bezusterkowy odbiór robót - dla gwarancji właściwego usunięcia wad lub usterek.

Wynik analizy ma odpowiedzieć na dwa podstawowe pytania: na czym polega objęte gwarancją zobowiązanie i w jakich sytuacjach beneficjent skieruje żądanie zapłaty (Kukiełka, Poniewierka 2003: 185). Treść umowy podstawowej lub SIWZ determinuje ponadto podstawowe parametry gwarancji: sumę gwarancyjną (np. 5\% wartości wynagrodzenia), okres odpowiedzialności (np. 2 lata od daty podpisania umowy), kluczowe fragmenty treści gwarancji (np. „nieodwołalna”, „, bezwarunkowa”, „płatna na pierwsze pisemne żądanie”, „płatna w terminie ... dni od daty otrzymania żądania wypłaty") bądź gotowy wzór wymaganego zabezpieczenia (stanowiący załącznik do umowy).

Niezwykle istotnym elementem oceny ryzyka jest zbadanie zdolności zobowiązanego do wykonania danego kontraktu. Podstawą tej analizy jest zbadanie zgodności kontraktu z dotychczasowym profilem działalności zobowiązanego (Kukiełka, Poniewierka 2003: 189): 
- w sensie przedmiotowym: „czy firma realizowała kontrakty o danym charakterze",

- w sensie ilościowym: „czy firma realizowała podobne kontrakty o zbliżonej wielkości/wartości”,

- w sensie wynikowym: „jak oceniono realizację powyższych kontraktów”.

Badaniu podlegają na tym etapie składniki materialne (aktywa, leasing), niematerialne (załoga) oraz referencje zobowiązanego.

Po przeanalizowaniu wszystkich wyżej wymienionych czynników dochodzi do kluczowego momentu, tj. podjęcia przez gwaranta decyzji o przyjęciu lub odrzuceniu ryzyka. Z uwagi na specyficzny charakter ubezpieczeń grupy 15., a szczególnie ich nieodwołalny i bezwarunkowy (w większości przypadków) charakter, ubezpieczyciel ma nikły wpływ na ograniczenie ryzyka po udzieleniu danej gwarancji. Nie ma też możliwości modelowania ryzyka, jak przy innych ubezpieczeniach: przez kształtowanie ogólnych warunków ubezpieczenia, wprowadzenie franszyz czy dołączanie dodatkowych klauzul. W przypadku wystąpienia szkód i wypłat jedynym sposobem na ratowanie wyników działalności gwarancyjnej staje się maksymalnie sprawne i szybkie wszczęcie oraz przeprowadzenie procedur związanych z regresem. Stąd istotne jest prawidłowe ustanowienie adekwatnych do danego ryzyka zabezpieczeń roszczeń zwrotnych oraz wyjątkowo wnikliwa ocena ryzyka przed udzieleniem danej gwarancji.

Firmy prowadzące działalność gwarancyjną obierają różnego rodzaju strategie związane z tą linią biznesową. Niektóre, choć formalnie mają możliwość sprzedaży ubezpieczeń grupy 15., w praktyce tego w ogóle nie robią, np. na koniec 2009 roku dwudziestu sześciu z trzydziestu czterech ubezpieczycieli działających w dziale II posiadało zezwolenie KNF na działalność w ramach grupy 15., a dwudziestu trzech z nich tę działalność rzeczywiście prowadziło (Nowak 2011: 101-102). Ponadto większość ubezpieczycieli specjalizuje się w wybranych rodzajach gwarancji - np. kontraktowych czy też turystycznych, i na ich podstawie rozbudowuje swój portfel oraz know-how. Bez względu na skalę prowadzenia działalności gwarancyjnej ubezpieczyciele podchodzą niezwykle sumiennie do analizy ryzyka związanego z działalnością gwarancyjną - wszak jedna poważna szkoda jest w stanie zachwiać rocznym wynikiem finansowym całego towarzystwa ubezpieczeń. 


\section{ZAKOŃCZENIE}

Ocena ryzyka w procesie udzielania ubezpieczeniowych gwarancji kontraktowych różni się istotnie od analogicznych procesów opracowanych dla pozostałych ubezpieczeń majątkowych. Procedury udzielania gwarancji determinuje specyficzny charakter tych produktów ubezpieczeniowych: nie jest możliwe statystyczne oszacowanie prawdopodobieństwa wystąpienia szkody, a każdorazowe udzielenie gwarancji (nawet dla stałego klienta) musi być poprzedzone precyzyjną analizą ryzyka. Ocenie podlega ryzyko zobowiązanego, ryzyko kontraktu oraz relacja między potencjałem intelektualnym i materialnym wykonawcy a wymaganiami określonymi w umowie podstawowej. Ubezpieczeniowe gwarancje kontraktowe mogą zabezpieczać wszystkie etapy procesu inwestycyjnego: od gwarancji zapłaty wadium, przez gwarancje należytego wykonania kontraktu, zwrotu zaliczki, aż po gwarancję właściwego usunięcia wad i usterek. Umożliwia to zobowiązanym zachowanie wyższej płynności i podniesienie wiarygodności w oczach kontrahentów.

Ze względu na wysoką zależność wyników działalności gwarancyjnej od fazy cyklu koniunkturalnego ubezpieczyciele muszą nieustannie modyfikować i doskonalić procedury oceny ryzyka. Gwaranci są zmuszeni zachowywać wysoką ostrożność nie tylko w fazie spowolnienia i recesji, ale także w czasie ożywienia i wzrostu, z uwagi na wieloletnie okresy odpowiedzialności z tytułu gwarancji.

\section{LITERATURA}

Gawrychowski M. (2012), Ubezpieczyciele ranieni gwarancjami, Puls Biznesu, http:// www.pb.pl/2645410,26970,ubezpieczyciele-ranieni-gwarancjami (dostęp: 1.08.2012).

Glapiak E. (2013), o gwarancje ubezpieczycieli trudniej, a ich brak to koniec firmy, Dziennik Gazeta Prawna, http://serwisy.gazetaprawna.pl/finanse-osobiste/artykuly/693386,o-gwarancje-ubezpieczycieli-trudniej-a-ich-brak-to-koniec-firmy.html (dostęp: 28.03.2013).

Holly R. (2004), Ubezpieczenia finansowe i gwarancje ubezpieczeniowe, Poltext, Warszawa.

Kukiełka J., Poniewierka D. (2003), Ubezpieczenia finansowe, Oficyna Wydawnicza Branta, Bydgoszcz-Warszawa.

Materiały Głównego Urzędu Statystycznego: http://stat.gov.pl/cps/rde/xbcr/gus/oz_ maly_rocznik_statystyczny_2012.pdf.

Materiały Komisji Nadzoru Finansowego: http://www.knf.gov.pl/opracowania/rynek_ ubezpieczen/index.html . 
Materiały ubezpieczycieli: wnioski o zawarcie ubezpieczeniowych gwarancji kontraktowych (Powszechny Zakład Ubezpieczeń SA, InterRisk Towarzystwo Ubezpieczeń SA Vienna Insurance Group, Gothaer Towarzystwo Ubezpieczeń SA, Towarzystwo Ubezpieczeń Wzajemnych TUZ).

Michalik L., Seliga D. (2001), Ubezpieczenia finansowe, [w:] Podstawy ubezpieczeń, t. 2: Produkty, J. Monkiewicz (red.), Poltext, Warszawa.

Nowak T. (2011), Rynek gwarancji ubezpieczeniowych w Polsce, Wiadomości Ubezpieczeniowe, nr 3.

Rozporządzenie Ministra Sportu i Turystyki z dnia 21 kwietnia 2011 r. w sprawie wzorów formularzy umowy gwarancji bankowej, umowy gwarancji ubezpieczeniowej oraz umowy ubezpieczenia na rzecz klientów, wymaganych w związku z działalnością wykonywaną przez organizatorów turystyki i pośredników turystycznych, Dz.U. z 2011 r., nr 88, poz. 499.

Sikora P. (2012), Jak zredukować ryzyko inwestycji, http://prawo.rp.pl/artykul/830861. html?print=tak\&p=0 (dostęp: 1.03.2012).

Towarzystwa ubezpieczeniowe zaostrza zasady udzielania gwarancji? (2012), http:// www.money.pl/gospodarka/wiadomosci/artykul/towarzystwa;ubezpieczeniowe; zaostrza;zasady;udzielania;gwarancji,89,0,1134937.html (dostęp: 1.08.2012).

Ustawa z dnia 22 maja 2003 r. o działalności ubezpieczeniowej, Dz.U. z 2003 r., nr 124, poz. 1151.

Ustawa z dnia 23 kwietnia 1964 r. Kodeks cywilny, Dz.U. z 1964 r., nr 16, poz. 93.

Ustawa z dnia 29 sierpnia 1997 r. Prawo bankowe, Dz.U. z 1997 r., nr 140, poz. 939.

Wierzbicka E. (2007), Ubezpieczenia finansowe w działalności przedsiębiorstwa, Rozprawy Ubezpieczeniowe, z. 3. 
